\title{
Sedimentary environment changes during the Early-Middle Pleistocene transition as recorded by the Daumantai sections in Lithuania
}

\author{
Valentinas BALTRŪNAS ${ }^{1, ~ *}$, Rimante ZINKUTE் ${ }^{1}$, Vaida ŠEIRIENE ${ }^{1}$, Valentas KATINAS ${ }^{1}$, \\ Bronislavas KARMAZA ${ }^{1}$, Dalia KISIELIENE ${ }^{1}$, Ričardas TARAŠKEVIČIUS ${ }^{1}$ and Lina LAGUNAVIČIENÉ ${ }^{1}$ \\ 1 Institute of Geology and Geography, Nature Research Centre, T. Ševčenkos 13, LT-03223, Vilnius, Lithuania
}

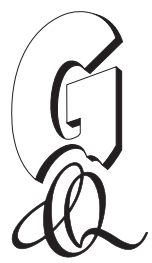

Baltrūnas V., Zinkutè R., Šeirienè V., Katinas V., Karmaza B., Kisielienè D., Taraškevičius R. and Lagunavičienè L. (2013) Sedimentary environment changes during the Early-Middle Pleistocene transition as recorded by the Daumantai sections in Lithuania. Geological Quarterly, 57 (1): 45-60, doi: 10.7306/gq.1076.

Two sections (Daumantai-1 and Daumantai-3) in East Lithuania expose Early-Middle Pleistocene lacustrine-alluvial, deposits which lie on a thin Neogene layer and on older Devonian rocks. They are overlain by glacigenic deposits. Geochemical, palaeomagnetic, magnetic susceptibility, plant macrofossil, and diatom investigations were performed to determine the changes in the sedimentary environment. Cluster analysis of the geochemical variables (10 major elements, 16 trace elements, total organic and inorganic carbon) revealed the element groups and factors. The lowermost units are characterized by a major influence of local material and significant fluctuations in heavy mineral content. These fluctuations might reflect short-term climate changes. The transitional units have more expressed trends, especially as regards the trace elements and $\mathrm{Zr} / \mathrm{Ti}$. The uppermost units are characterized by a slight influence of local material and small fluctuations in trace elements. The data analysed enable the subdivision of the section into units related to changes in sedimentary environment. The boundary of the Bruhnes/Matuyama reversal in the Daumantai-1 and Daumantai-3 sections was detected by palaeomagnetic studies and enables the stratigraphical correlation of these deposits.

Key words: Early-Middle Pleistocene, environmental changes, geochemistry, magnetic susceptibility, plant macroremains, Lithuania.

\section{INTRODUCTION}

Early-Middle Pleistocene deposits have been found in central and eastern Europe in many places (e.g., Yakubovskaya, 1998; Ber, 2000; Makhnach et al., 2001; Lindner et al., 2004, 2006; Ber et al., 2007; Lindner and Marks, 2008; Winter et al., 2008). Ascertaining the positions of the Matuyama and Brunhes chrons in the Belarus Quaternary sequence and new stratigraphic results in Lithuania has enabled revision of the Eopleistocene stratigraphy in this region (Early/Lower Pleistocene of Western Europe; Yakubovskaya, 1998; Makhnach et al., 2001; Lindner et al., 2004). The aim of this study is a detailed analysis of the changes in sedimentary environment and the location of the Middle-Early Pleistocene boundary. For this purpose, new data from geochemical (e.g., trace elements, organic and inorganic carbon), palaeobotanical (plant macroremains), palaeomagnetic and magnetic susceptibility investigations have been used.

The Daumantai and Vetygala exposures in the Anykščiai district have been studied since the first half of the last century

\footnotetext{
* Corresponding author: baltrunas@geo.It

Received: May 29, 2012; accepted: September 5, 2012; first published online: February 24, 2013
}

(Dalinkevičius, 1928, 1944; Kaveckis, 1928). These sections were of interest because the Neogene-Quaternary boundary was thought to be present within them. The deposits of the Daumantai Formation have been regarded by Halicki (1938), Dalinkevičius (1944) and Vaitiekūnas (1977) as Pre-glacial or Pre-Pleistocene. They have been studied using palaeobotanical (Baltakytè -Vienožinskienè, 1956; Kondratienè, 1996; Kisielienè, 2002), lithological, and petrographic (Klimašauskas and Prakapaitè, 1971; Vaitiekūnas, 1977; Malinauskas, 1985; Gaigalas, 1987; Narbutas and Uginčius, 2001; Šinkūnas et al., 2001) methods. Palaeomagnetic results had not been successfully retrieved (Pevzner and Gaigalas, 1976), because of the limitations of the measuring technique. From a stratigraphical point of view, the boundary was supposedly located between the Neogene and either the Pleistocene - Eopleistocene (Kondratiené, 1996) or the Prepleistocene (Gaigalas, 1995; Baltrūnas, 2002; Satkūnas et al., 2007). Lithological and geochemical studies allowed genetic identifications and establishment of the hydrodynamic sedimentary environment represented by the deposits. Nevertheless, the stratigraphical interpretation (Kondratienè et al., 2001; Šinkūnas et al., 2001) and its correlation with the western European stratigraphical divisions remain problematic. The upper stratigraphical boundary of the Daumantai Stage corresponds to the lower limit of glacial deposits, attributed to the oldest continental glaciation, during which ice extended as far south as the latitude of eastern Lithu- 
ania (Guobytè and Satkūnas, 2011). The Daumantai Stage strata in Lithuania are covered by glacial and interglacial deposits up to 314 m thick. Around Daumantai, the Quaternary deposits are very thin (up to $30 \mathrm{~m}$ ) and are represented by glaciolacustrine deposits of the Kalviai (Menapian) Glaciation and by till of the Nemunas (Weichselian) Glaciation (Table 1).

\section{STUDY SITE AND MATERIAL}

The Daumantai-1 exposure is situated in north-east Lithuania, approximately $5 \mathrm{~km}$ from the town of Kavarskas (24ㄷำ E/ $55^{\circ} 26^{\prime} \mathrm{N}$ ), on the west bank of the Šventoji River, near the village of Daumantai (Fig. 1). Approximately $200 \mathrm{~m}$ downstream from the Daumantai- 1 exposure, deposits some $6.7 \mathrm{~m}$ thick are exposed at Daumantai-3. Near the village of Daumantai, the valley of the Šventoji River is incised into the undulating surface of a moraine plateau. The valley slopes are approximately $28 \mathrm{~m}$ high and expose Devonian, Neogene and Quaternary strata. The "Pre-Pleistocene" investigated deposits overlie Devonian and Neogene rocks and are covered by glacial deposits (Kondratienè, 1996; Kondratienè et al., 2001). The Daumantai area is located on a sub-Quaternary surface, which reaches 40-60 m a.s.I., beside the confluence of two palaeoincisions (the palaeoŠventoji and palaeo-Virinta rivers; Šliaupa, 2004; Fig. 2). The bottom of these palaeoincisions is from 18 to $95 \mathrm{~m}$ below sea level. The sub-Quaternary elevations are commonly composed of Upper Pleistocene glacigenic deposits, locally covering Neo-

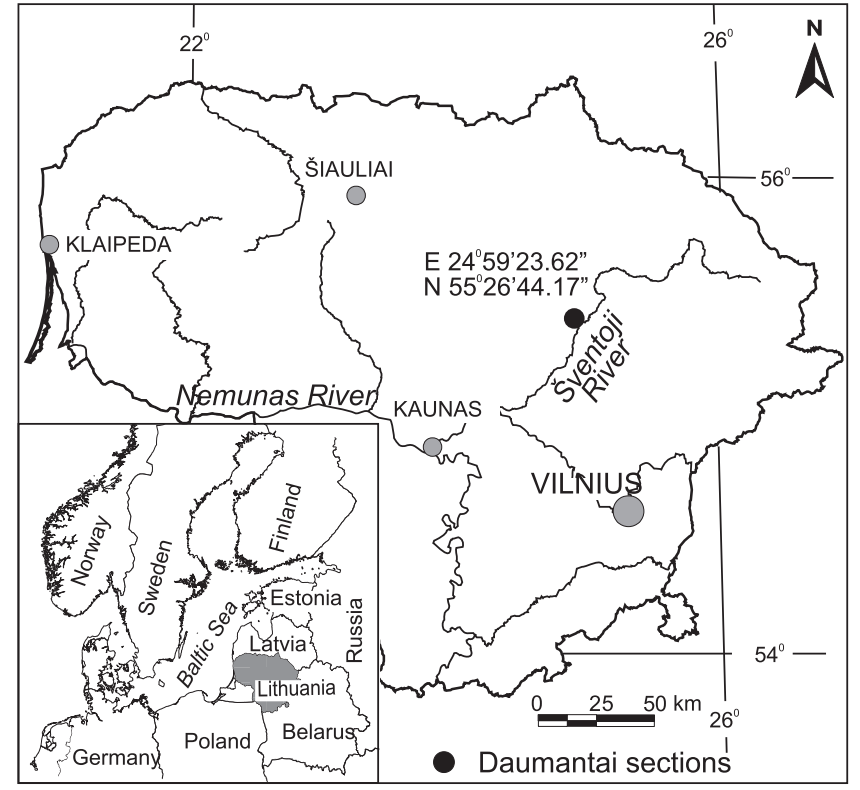

Fig. 1. Map of the area investigated

gene and Lower Pleistocene strata. Middle Pleistocene glacigenic deposits mostly occur within the palaeoincisions.

Detailed structural, textural and compositional investigations of the Daumantai section were performed in 2001 (Šinkūnas et al., 2001; Kondratienè et al., 2001). The studies enabled the deposits to be subdivided

Ta ble 1 into six units. Recently acquired data are consistent with this subdivision (Table 2 and Fig. 3). From units V, IV and III, 156 samples were collected for the determination of the total contents of major and trace elements, total organic carbon (TOC), total inorganic carbon (TIC), magnetic susceptibility (MS) and palaeobotanical analysis. Unit VI was sampled only for palaeobotanical data to reveal the vegetational changes because its previously established Neogene (Pliocene) age (Kondratiene, 1996); it has not been part of the recent investigations; the Daumantai-3 exposure includes Quaternary deposits only in the upper part of the section $(0.0-2.0 \mathrm{~m})$, these being represented by sand of various grain sizes. At the bottom of the sand layer there is an admixture of gravel. Below the sand, a layer at 2.0-4.4 m was attributed to the Neogene and comprises interbedded silty clay and sandy silt with organic matter. This interval was sampled for palaeomagnetic data to constrain the Neogene/Quaternary boundary.

\section{METHODS}

Determination of total contents of major and trace elements. Element contents were measured using energy-dispersive x-ray fluorescence (EDXRF) Spectro Xepos equipment and the Turboquant calibration method, for pressed pellets. 


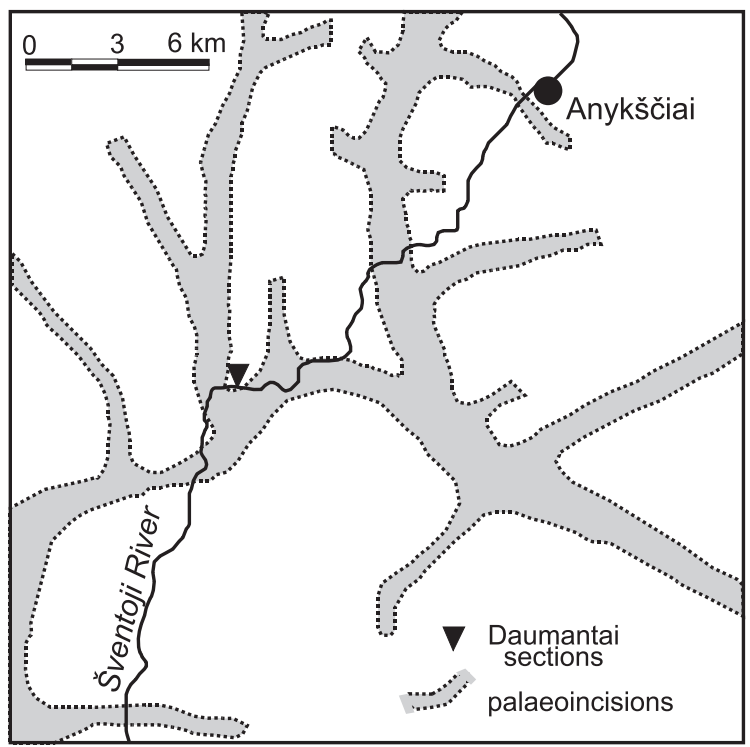

Fig. 2. Palaeoincisions in the sub-Quaternary surface near Daumantai (by Šliaupa, 2004)
Determination of the TOC and TIC. For determination of total carbon, liquiTOC equipment was used. This determination is based on the high-temperature oxidation method (Tiessen and Moir, 1993). The sample is ashed at a temperature not less than $+900^{\circ} \mathrm{C}$ and the concentration of the $\mathrm{CO}_{2}$ is measured by non-dispersed infrared detector (NDIR). The mass of the milled subsample used for this analysis was 70-800 mg. For the daily quality control before starting the measurements, the carbon content of $\mathrm{CaCO}_{3}$ was measured (it is $12 \% \mathrm{C}$ ). Some of the samples were measured repeatedly. The TOC was determined in the same manner, but before the analysis, the inorganic carbon was eliminated from the homogenized subsample using $0.5 \mathrm{M} \mathrm{HCl}$. The TIC was calculated as the difference between total carbon and the TOC. All of the results were expressed as percentages.

Determination of magnetic susceptibility. The mass magnetic susceptibility $\left(\mathrm{m}^{3} / \mathrm{kg}\right)$ of the 156 samples from the Daumantai-1 section was measured at the Institute of Geology and Geography, Nature Research Centre by a kapabridge MFK-1B (AGICO Czech Republic); the volume magnetic susceptibility of 26 samples from the Daumantai-3 section in Polish Geological Institute - National Research Institute was measured by a kapabridge KLY-2 (AGICO Czech Republic). The latter data were recalculated for a 10-g sample size. For each section, a diagram of magnetic susceptibility versus depth was constructed.

Palaeomagnetic investigations. The natural remanent magnetization of 24 samples from the Daumantai- 1 section and

Table 2

Short description of the Daumantai-1 section

\begin{tabular}{|c|c|c|}
\hline $\begin{array}{l}\text { Depth of the } \\
\text { lower boundaries } \\
\text { of the layers [m] }\end{array}$ & Short description according to Kondratienè et al. (2001) & $\begin{array}{l}\text { No } \\
\text { of units* }\end{array}$ \\
\hline 2.20 & till brown with gravel, pebbles and boulders & - \\
\hline 2.90 & silt yellowish grey, fine-grained, massive and slightly wavy-laminated & III \\
\hline 4.00 & silt greenish grey, fine-grained, massive, with organic matter & III \\
\hline 6.05 & silt brownish grey, fine-grained, massive and micro-laminated & III \\
\hline 6.80 & sand white, very fine-grained, wavy-laminated & III \\
\hline 7.80 & silt light grey, coarse, massive, the bed is inclined to the direction of $330^{\circ}$ & III \\
\hline 8.60 & sand grey, fine-grained, wavy laminated, the bed is inclined to the direction of $320^{\circ}$ & III \\
\hline 9.55 & horizontal interbedding of grayish-brown silt with brownish-grey very fine-grained sand & III \\
\hline 10.50 & silt grayish-brown, fine-grained, massive & III \\
\hline 12.80 & $\begin{array}{l}\text { horizontal interbedding of grayish-brown silt, fine-grained, laminas of } 2-5 \mathrm{~cm} \text { thick, } \\
\text { with white very fine-grained sand }\end{array}$ & IV \\
\hline 13.40 & sand white, middle-grained, with indistinct ripple marks & IV \\
\hline 15.00 & sand white, fine-grained, ripple and wavy bedded with rare silt laminas & IV \\
\hline 15.95 & $\begin{array}{l}\text { sand grey and light grey, very fine-grained and fine-grained, } \\
\text { wavy bedded with lamina thickness of } 0.2-1.0 \mathrm{~cm}\end{array}$ & IV \\
\hline 17.45 & sand grayish-white, fine-grained, fine wavy bedded with silt lamina of $10 \mathrm{~cm}$ thick & IV \\
\hline 17.75 & $\begin{array}{c}\text { sand grey, various-grained with middle-grained prevailing with organic admixture, } \\
\text { the bed has a shape of lens and is inclined to the direction of } 340^{\circ}\end{array}$ & V \\
\hline 19.15 & sand grey, middle-grained passing to fine-grained upwards with silt laminas of $3-5 \mathrm{~cm}$ thick & $\mathrm{V}$ \\
\hline 19.95 & $\begin{array}{l}\text { sand brown due to limonite pigmentation, various-grained with fine-grained prevailing, ripple } \\
\text { and subhorizontally bedded, the bed is inclined with dip angle of } 20^{\circ} \text { to the direction of } 340^{\circ}\end{array}$ & $\begin{array}{l}\text { VI, Neogene } \\
\text { (Pliocene) }\end{array}$ \\
\hline 20.45 & silt grayish-brown with fine-grained sand laminas & $\begin{array}{l}\text { VI, Neogene } \\
\text { (Pliocene) }\end{array}$ \\
\hline 24.40 & $\begin{array}{l}\text { sand yellowish white and grey, with limonite pigmentation, } \\
\text { fine-grained, horizontally laminated and ripple bedded }\end{array}$ & $\begin{array}{l}\text { VI, Neogene } \\
\text { (Pliocene) }\end{array}$ \\
\hline 25.40 & sandstone yellowish-brown, rocky & Devonian \\
\hline
\end{tabular}

* - units are according to Šinkūnas et al. (2001) 


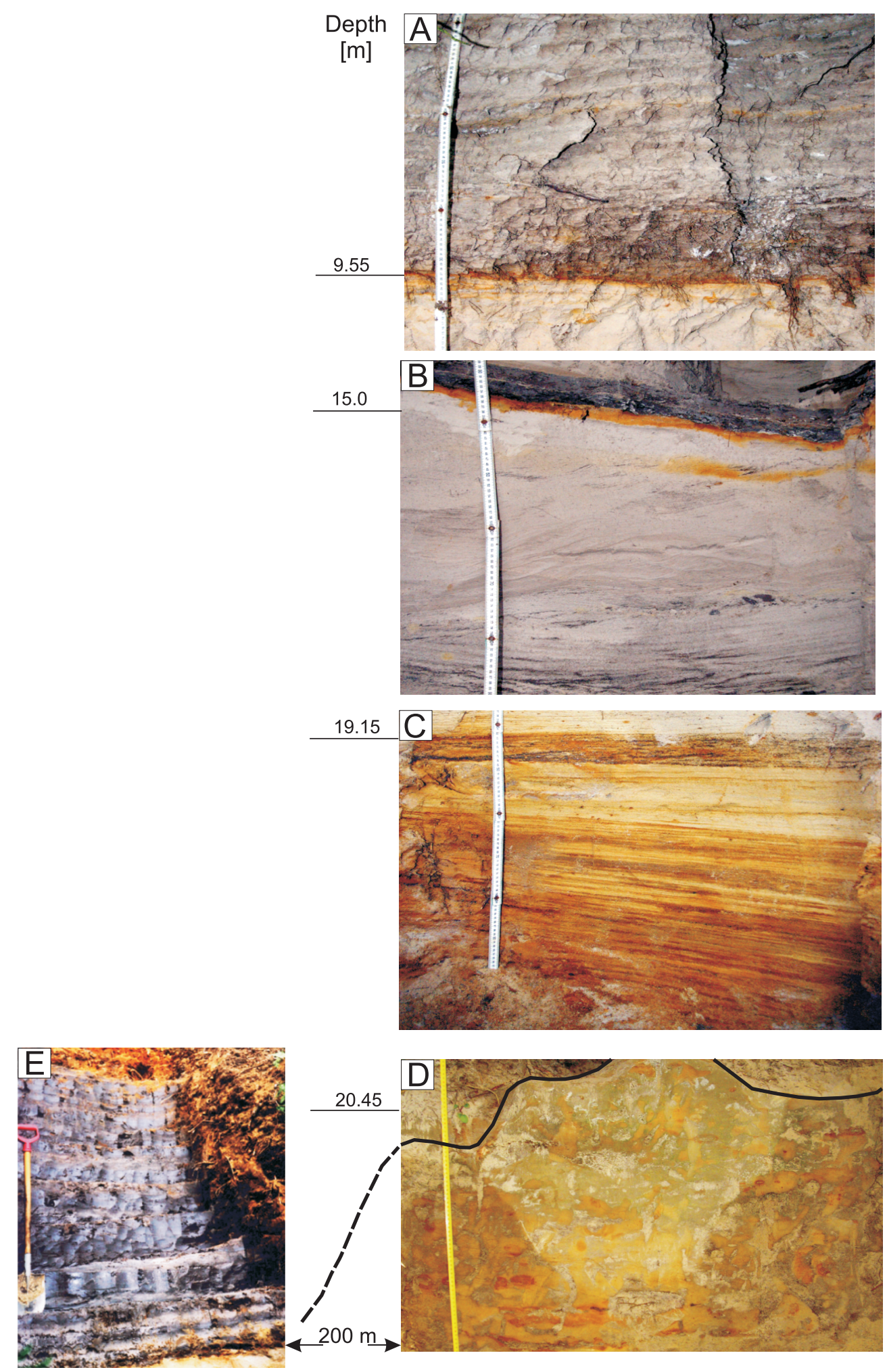

Fig. 3. Parts of the Daumantai-1 (A, B, C, D) and Daumantai-3 (E) sections

Photo by B. Karmaza (A-D) and P. Šinkūnas (E)

of 26 samples from the Daumantai-3 section was measured using a JR-6 spinner magnetometer at the Polish Geological Institute - National Research Institute. The magnetic declination and magnetic inclination were determined and plotted for each sample. All of the samples were subjected to stepwise alternating field (AF) demagnetization. The results of the demagnetiza- tion of the samples were obtained as stereographic projections, $\mathrm{I}_{\mathrm{rm}} / \mathrm{I}_{\mathrm{nrm}}$ and $\mathrm{x}, \mathrm{y}, \mathrm{z}$ projections.

Plant macroremain analysis. From the layers selected, 20 samples were examined for plant macroremains. Each sample covers an interval of up to $5-10 \mathrm{~cm}$. Only 13 samples contained plant macroremains. These have been extracted from the sedi- 
ment samples (7-10 I in volume) by wet sieving (screens with mesh sizes of 0.2 and $0.5 \mathrm{~mm}$ ). The identification of the material collected was based on Berggren (1969, 1981), Grigas (1986) and Cappers et al. (2006) in conjunction with the reference collection at the Institute of Geology and Geography, Nature Research Centre, Vilnius. The plant macroremains are shown in a diagram as various identified specimens/sediment volumes; the botanical nomenclature follows that described in Gudžinskas (1999).

Diatom investigations. For the diatom analysis, 40 samples from all lithological units were taken. The diatom frustules were extracted from the sediments in the conventional manner described by Battarbee (1986) and by Miller and Florin (1989).

\section{STRUCTURAL, COMPOSITIONAL AND CHRONOLOGICAL CHARACTERISTICS OF THE DAUMANTAI-1 SECTION}

\section{GEOCHEMICAL RESULTS}

Comparison of units. The relative median content of Si decreases upwards from unit III to unit $\mathrm{V}$, while contents of the other nine major elements, the TOC, TIC and all 16 trace elements increase (Fig. 4A). For most chemical elements, the increase in the relative median content from unit IV to unit III is more pronounced than that from unit $V$ to unit IV (Fig. 5A). The lower two units (V and IV) are also characterized by low TIC content. The $\mathrm{Ca}$ and $\mathrm{Mg}$ content in these two units is extremely low. Also in the two lower units, there was noted the largest quantity of samples with $\mathrm{Na}$ content below the detection limit.

The highest coefficients of variation of most of the major and trace elements (17), as well as of the TIC and TOC, are in unit $\mathrm{V}$; only eight elements ( $\mathrm{Na}, \mathrm{P}, \mathrm{Zn}, \mathrm{Sr}, \mathrm{Mn}, \mathrm{Zr}, \mathrm{Hf}, \mathrm{Y}$ ) are characterized by the highest coefficients of variation in unit IV and one (Si) in unit III (Fig. 4B). The coefficients of variation of the 17 variables decrease upwards and are the lowest in unit III. The highest coefficient of variation values in unit $\mathrm{V}$ are the result of three silt interlayers, which are enriched in all chemical elements except Si. The content of organic carbon increases in these interlayers as well. The TIC, which reflects the carbonates, is elevated only in the interlayer at a depth of $17.15 \mathrm{~m}$.

Distribution of the factor scores and ratios of elements. The three factors that were distinguished according to 28 variables (10 major elements, 16 trace elements, TIC and TOC) exhibit associations similar to those in the dendrogram (Fig. 6). The scores of two different main factors were compared: F1mc distinguished according to 12 variables and F1all distinguished according to 28 variables. The variation of these scores is very similar; more distinct cycles being identified in the upper two units. The distribution of the scores of F2all slightly differs from

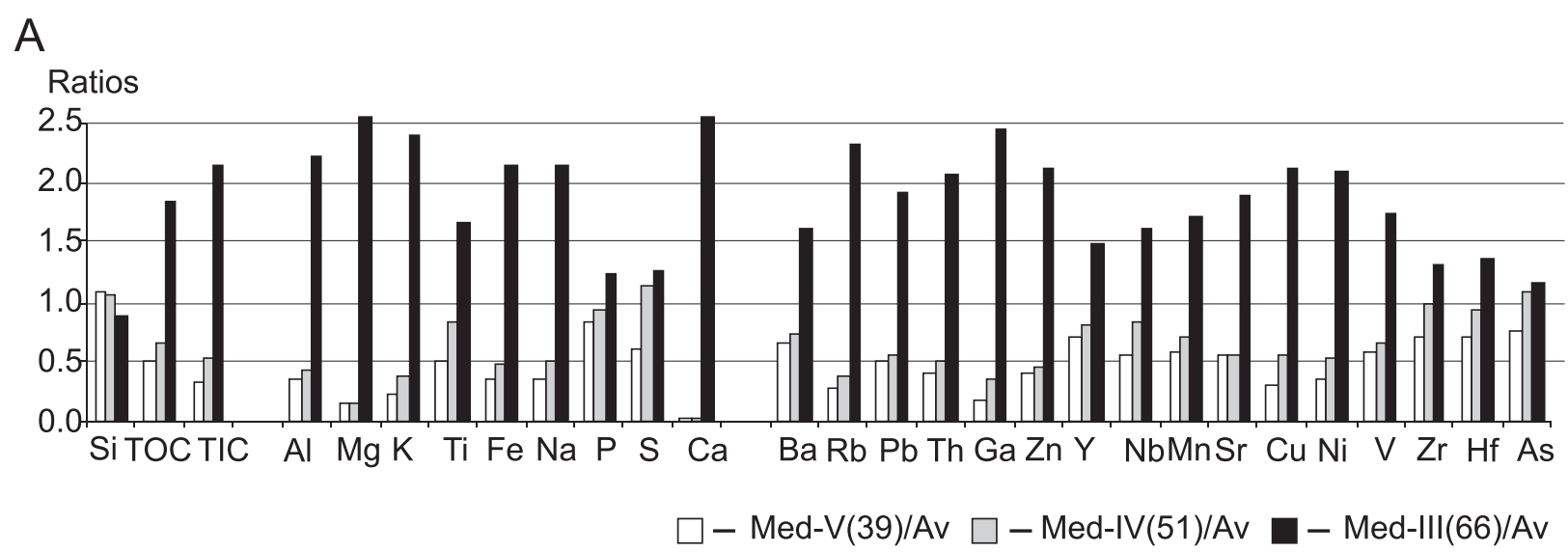

B

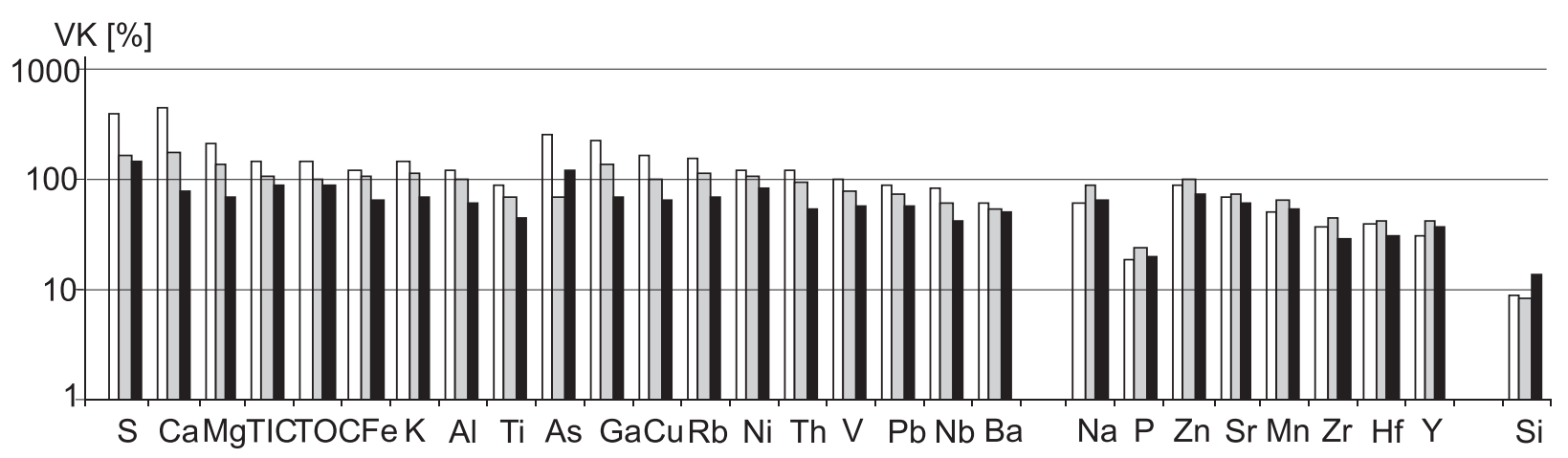

$$
\square-V K-V \square-V K-I V \quad \square-V K-I I I
$$

Fig. 4. Geochemical comparison of the units

A - normalised median contents of elements and median TOC and TIC contents in units; Med-V(39)/Av, Med-IV(51)/Av, Med-III(66)/Av are normalised median contents in units (normalisation means dividing by average value in the interval analysed; the number of samples is in parentheses); B - coefficients of variation: VK-V - in unit V, VK-IV - in unit IV, VK-III - in unit III; logarithmic scale is used 


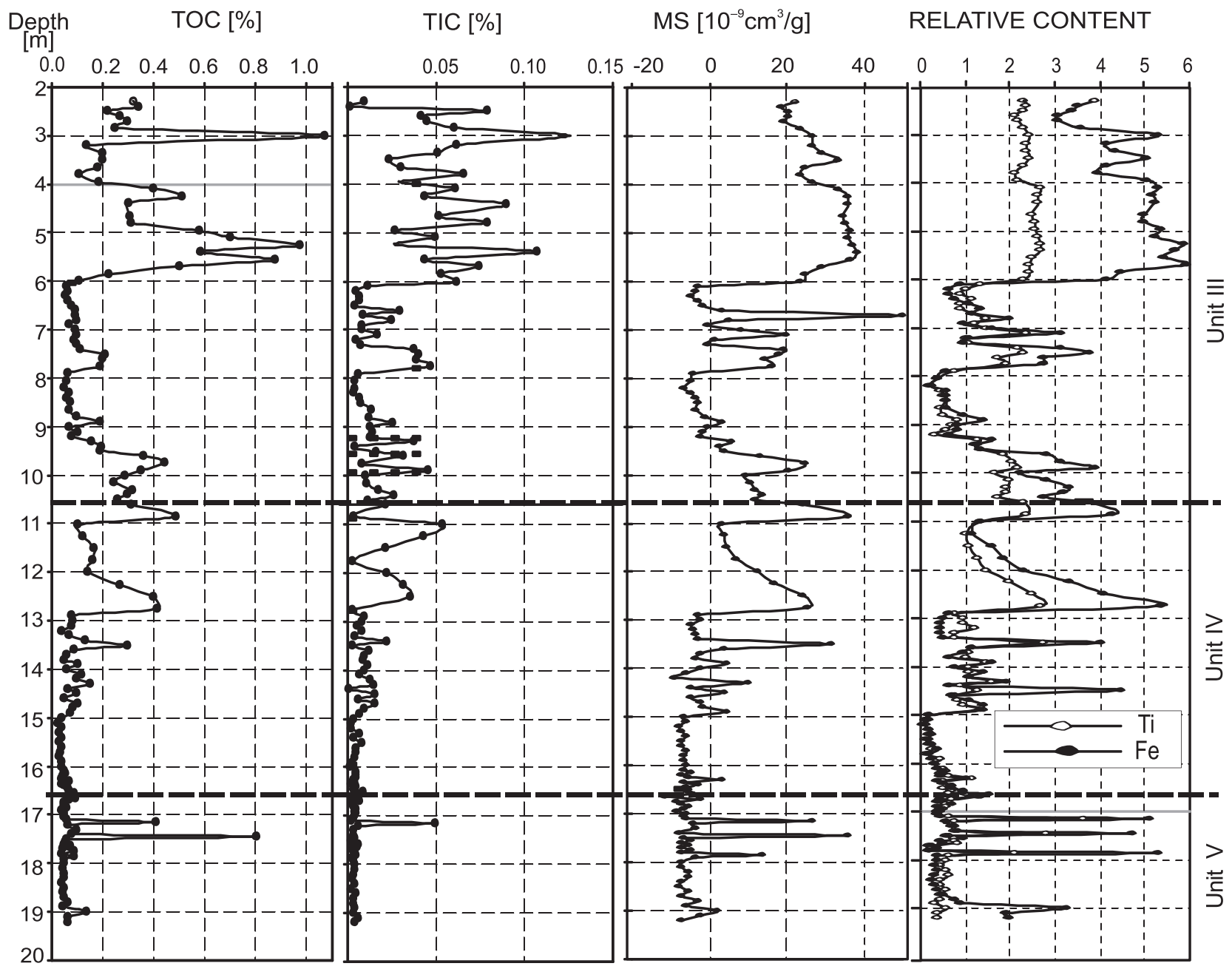

Fig. 5. Distribution of total organic carbon (TOC), total inorganic carbon (TIC), magnetic susceptibility (MS) and relative content of $\mathrm{Fe}$ and $\mathrm{Ti}$

the distributions of $\mathrm{F} 1 \mathrm{mc}$ and $\mathrm{F} 1$ all. The distributions of the scores of factors F2mc and F3all are also very similar.

The distribution pattern of $\mathrm{Al} / \mathrm{Si}$ (Fig. 7) is very similar to the distribution pattern of F1all (Fig. 8). This similarity is quite natural because $\mathrm{Si}$ has the most negative loading and $\mathrm{Al}$ the most positive loading on F1all. The distribution pattern of $\mathrm{Ca} / \mathrm{Zr}$ is analogous (Fig. 7). The distribution of $\mathrm{Zr} / \mathrm{Ti}$ differs from the distribution of all three factors, including F2all.

Because of the information contained in the distribution pattern of the F1all scores, 11 boundaries and 12 units were distinguished according to this variable, which has a distribution similar to the $\mathrm{Al} / \mathrm{Si}$ ratio. After this subdivision of the section in each unit, the distribution of the other seven variables has been analysed: F2all, F3all, TOC, TIC, MS, Ca/Zr and Zr/Ti. The relationship between F1all and F2all has also been taken into account.

\section{CORRELATION OF MAGNETIC SUSCEPTIBILITY WITH CHEMICAL ELEMENTS AND ITS DISTRIBUTION}

In the Daumantai- 1 section, the correlation of the magnetic susceptibility (MS) with almost all of the chemical elements, ex- cept $\mathrm{Si}$, is significant and positive $(\mathrm{p}<0.001$ for all elements and $0.05>p>0.001$ for As); only with $\mathrm{Si}$ is the correlation significant $(p<0.001)$ and negative $(-0.93)$.

In the lower two units ( $\mathrm{V}$ and IV), the median values of mass magnetic susceptibility are negative: $-5.9 \times 10^{-9} \mathrm{~cm}^{3} / \mathrm{g}$ and -3.4 $\times 10^{-9} \mathrm{~cm}^{3} / \mathrm{g}$, respectively. The upper unit is characterized by a positive median MS: $15.4 \times 10^{-9} \mathrm{~cm}^{3} / \mathrm{g}$.

The distribution pattern of the MS in the Daumantai- $1 \mathrm{sec}-$ tion is very similar to the distribution pattern of Fe, Ti (Fig. 5) band the other chemical elements with positive loadings on the first factor F1all. The peaks of the scores of this factor are often at the same depth where the MS has a positive peak.

There are only four samples in the lower unit $(V)$ where the MS > 0 (Fig. 5). The samples are from the three previously mentioned silt interlayers, and the distribution pattern of the relative content of $\mathrm{Fe}$ and $\mathrm{Ti}$, reveals three peaks at these levels.

The percentage of the samples where MS > 0 increases in the upper units: $33.3 \%$ in unit IV and $72.7 \%$ in unit III. There are coinciding peaks of $\mathrm{Fe}$ and $\mathrm{Ti}$ at depths of 13.5 and $12.75 \mathrm{~m}$; however, there is only an Fe peak but not a Ti peak at a depth of $14.5 \mathrm{~m}$. The peaks of Fe more or less coincide with peaks of $\mathrm{Ti}$ in the lower part $(6.0-10.6 \mathrm{~m})$ of unit III. The upper part (2.3-6.0 m) of unit III with silt has a MS > 0; the MS ranges from $18.5 \times 10^{-9}$ to $36.7 \times 10^{-9} \mathrm{~cm}^{3} / \mathrm{g}$. 
Tree diagram for 29 variables

Ward`s method

1-Pearson $r$

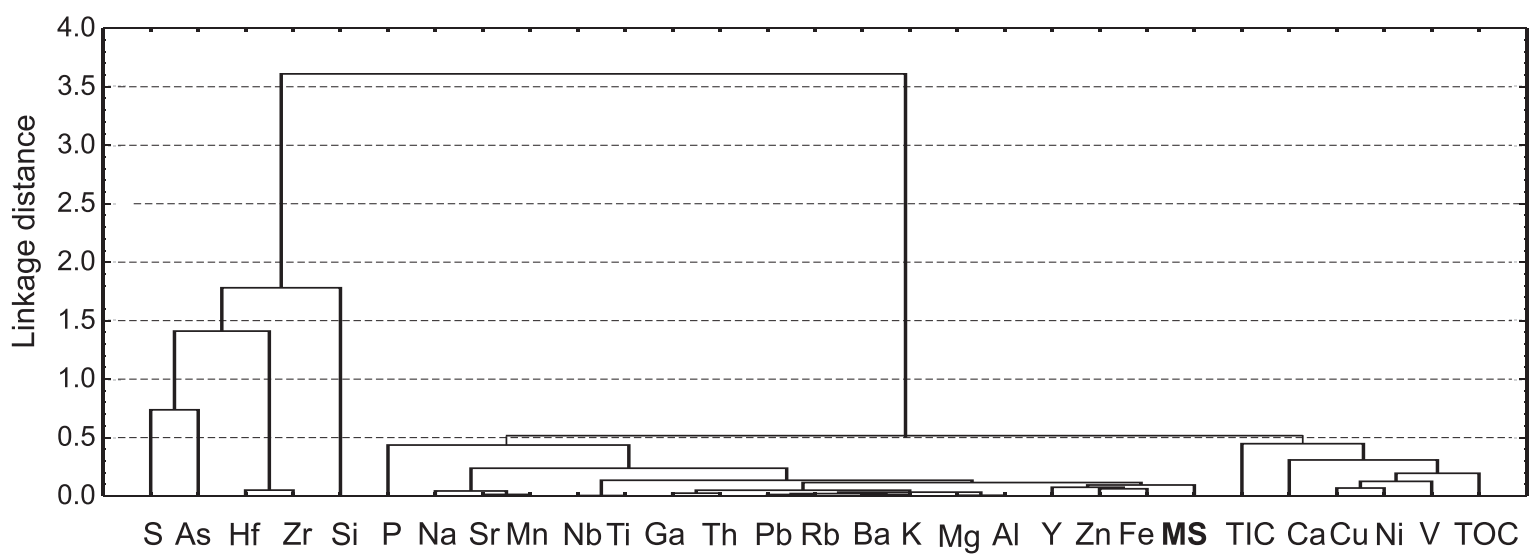

Fig. 6. Cluster analysis dendrogram of magnetic susceptibility and geochemical variables

\section{RESULTS OF PALAEOMAGNETIC AND MAGNETIC SUSCEPTIBILITY STUDIES}

In the Daumantai-1 section at a depth of $16.5 \mathrm{~m}$, the Brunhes/Matuyama magnetic reversal chron boundary $(0.78 \mathrm{Ma})$ was determined. This boundary was fixed in the nearby Daumantai-3 exposure at a depth of $2.1 \mathrm{~m}$. In the Daumantai-3 exposure, at a depth of $3.0 \mathrm{~m}$, the Jaramillo subchron (0.99-1.07 Ma) in the Matuyama chron was also determined (Figs. 9 and 10). The recently obtained data may be related to those of Richmond (1996), Gibbard and Kohen (2008) and Cohen and Gibbard (2011).

An example of progressive alternating-field (AF) demagnetization behaviour is shown on the orthogonal plots and equalarea projections in Figure 9. As the natural remanent magnetization (NRM) intensities before demagnetization are on the order of $10^{-4} \mathrm{~A} / \mathrm{m}$, the samples can be reliably measured with the $J R-5$ spinner magnetometer from AGICO.

The stepwise AF demagnetization portrays two kinds of overprints in the samples from the Daumantai-1 section. All of the samples contained a small coercivity component, removed in a field of approximately $10 \mathrm{mT}$. The second component was removed in a field of approximately $30 \mathrm{mT}$. The results of demagnetization demonstrate that all of the samples from the upper part of the Daumantai-1 section have a normal-polarity direction and one sample from the lower part represents a reversed polarity direction. All samples from the lower part of Daumantai-3 section, by contrast, have reversed-polarity directions and one sample from the upper part represents normal-polarity.

\section{RESULTS OF PALAEOBOTANICAL RESEARCH}

Three plant macroremain zones (PMRZ) were identified in the Daumantai-1 section (Fig. 11). The palaeocarpological assemblages are poor in macroremains as well as in variability of taxa.

The identified macroremains of the PMRZ 1a-m; 20.05-21.25 m (unit VI), consists of heterosporic plants (i.e., Salvinia glabra Nikit., S. intermedia Nikit., S. aphtosa Wieliczk.,
Azolla pseudopinnata Nikit.), which is characteristic of the Pliocene. Thus, the Pliocene macroflora consists of extinct species mainly representing the community of a shallow water basin. Typical forest zone plants are not present. Only needles of Pinus have been found. The old species Salvinia glabra and Azolla pseudopinnata (PMRZ 1b-m) are also present in the thin layer of sandy silt at a depth of $16.20-16.55 \mathrm{~m}$ (unit IV). They are accompanied by Selaginella selaginoides Link. This species is common in the initial and final stages of Pleistocene interglacials and interstadials, when the climatic conditions were cool. The species of Salvinia demand warmer environments. Thus, the possibility that megaspores of an extinct species were washed into this layer cannot be excluded. According to the previously compiled palynological data, tree pollen (AP) constitues as much as $70-80 \%$ of total pollen sum (predominantly Pinus). The Neogene elements such as Taxodium, Sciadopitys and Pinus Haploxylon type, as well as single grains of Tsuga, Juglandaceae, Nyssa, Celtis, Ostrya and Myrica etc., are also present in this part of the section (Kondratienè, 1996).

The palaeoflora of PMRZ 2-m; 8.6-12.8 $\mathrm{m}$ is characterized by a domination of Azolla interglacialis Nikit megaspores and the sporadic remains of extant plants, such as Salvinia natans (L.) All., Alisma plantago-aquatica L. and Pinus sp. The paucity of plant macroremains does not allow for precise reconstruction of the environmental conditions, when sedimentation of this part of the section was taking place.

According to the pollen and spore data, coniferous taxa still prevail in the section, but a higher amount of broad-leaved pollen occurs in the deposits studied, with the presence of Quercus (up to $12 \%$ ), Tilia (up to $3 \%$ ), Ulmus, Acer, Fagus, Pinus Haploxylon type and others (Kondratienè, 1996).

The PMRZ 3-m: 3.43-7.60 m is significantly richer in plant macroremains. A variability of species is characteristic of this flora (i.e., elements of different age are present in the same layers). Some extinct species coming from the Pliocene (Ranunculus sceleratoides Nikit. et Dorof., Elatine hydropiperoides Dorof. et Wieliczk.) as well as the Pleistocene species (e.g., Sparganium hyperboreum Laest., Eleocharis palustris L., Lycopus europaeus L., Potamogeton filiformis Pers., P. rutilus Wolfg., P. pussilus L., Ranunculus gmelini DC.) are present. The plant macrofossils determined indicate slightly cool condi- 


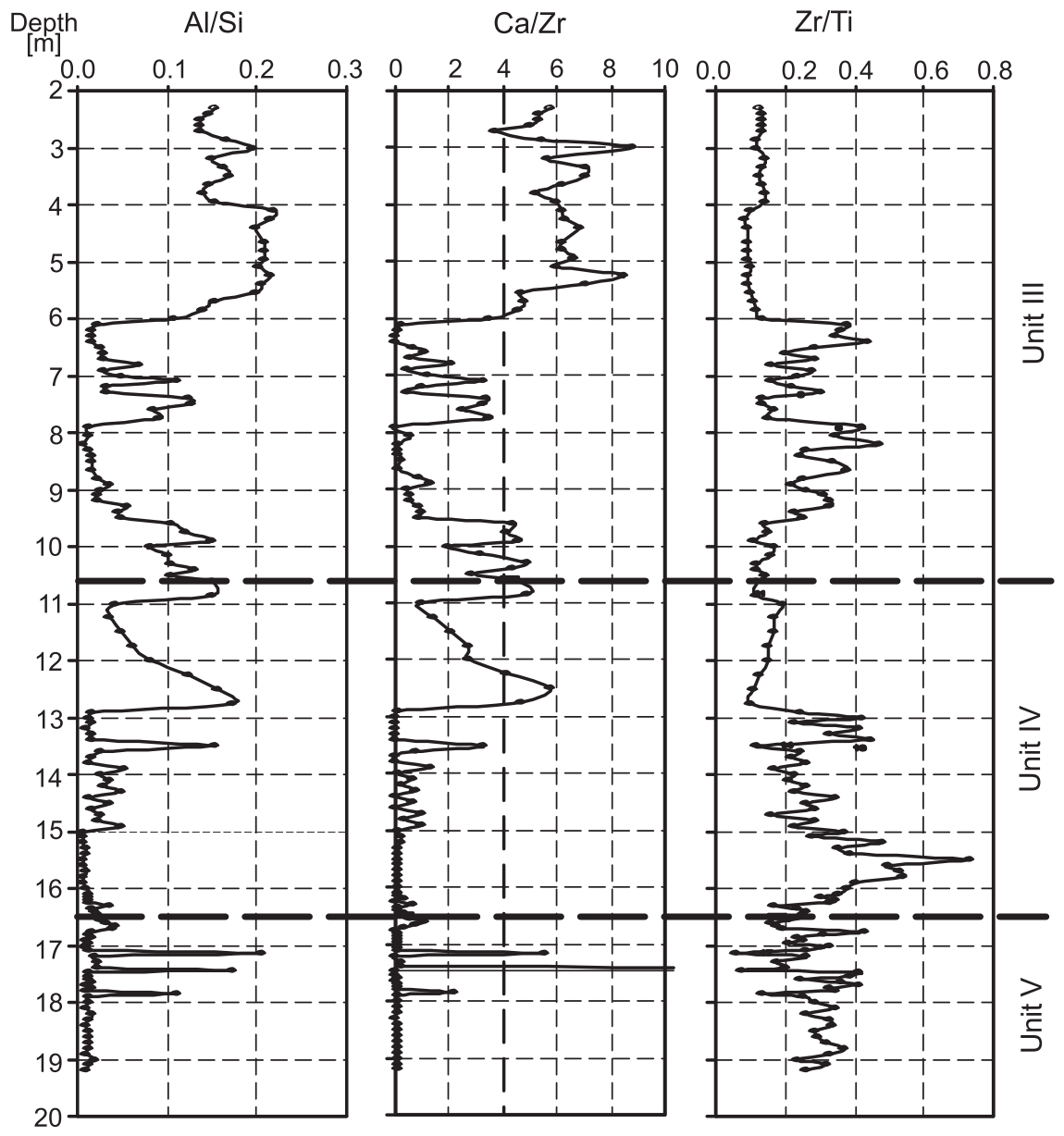

Fig. 7. Distribution pattern of several element ratios

tions, similar to the present-day climate. A major part of the flora is composed of a eurythermic species, which belongs to a group of plants typical of stagnant or slowly flowing water. The remains of trees indicate that mixed coniferous and deciduous woods had grown there, dominated by conifers with some Betula and Alnus. The palynological data suggest the presence also of Quercus, Ulmus, Tilia, Carpinus and Corylus (Kondratienè, 1996).

Diatoms were analysed from the sediment interval 3-22 m depth (units III-VI). The sediments are very poor in diatoms, and only single frustules were observed. From the 40 samples analysed, only 12 , occurring at different depths, contain diatoms. Representatives of the genera Fragilaria, Pinnularia, Navicula, Nitzschia, Aulacoseira and Cyclotella are the most common. Some extinct species, such as Paralia sulcata, Paralia sulcata var. crenulata and Stephanopyxis turris, are present, as well as some brackish water species (e.g., Cocconeis scutellum, Actinoptyhus undulates), indicating re-deposition of the sediments. Possibly, the variable sedimentation conditions were not favourable for the growth of diatoms.

The fossil flora of the Daumantai-1 section is not very rich in species, and at some intervals lacks palaeobotanical data completely. Our studies only permit partial reconstruction of the past vegetation and environmental changes. Nevertheless, according to previous pollen studies (Kondratiené, 1996; Kondratiené et al., 2001) and recent investigations it could be concluded that the upper part of the section differs from the remainder. There are more features of a periglacial landscape in its composition: the prevalence of non-arboreal pollen; the richest variability in herb species composition; the largest number of kserophytes; the prevalence of Betula up to $80 \%$ (including Betula nana) and Salix (up to 25\%) among arboreal taxa; the prevalence of Sphagnum among the spores; the appearance of representatives of subarctic flora such as Selaginella selaginoides L. (Link). The new species Selaginella tetraedra Wieliczk., Potamogeton perforatus Wieliczk. and Myriophyllum subspicatum Wieliczk. instead of the extinct ones mentioned above, have been detected there as well. Consequently, the floral composition of the upper part of the section is characteristic of open landscapes with shrub and herb communities and indicators a climate colder than today. According to the pollen and plant macrofossil data, the Neogene/Quaternary boundary may provisionally be fixed at the interval of $17-18 \mathrm{~m}$, because of the above mentioned features and the abundance of species characteristic of the Neogene (Kondratienè and Riškienè, 1971; Velichkievich, 1982)

\section{DISCUSSION}

\section{GEOCHEMICAL DIFFERENCES OF UNITS V, IV AND III}

The lower units (IV, V), represented by sand, consist mainly of quartz; the admixture of organic matter, carbonates, sulphides and non-quartz silicate minerals is very low. However, the admixture greatly increases in the upper unit. The high Si 


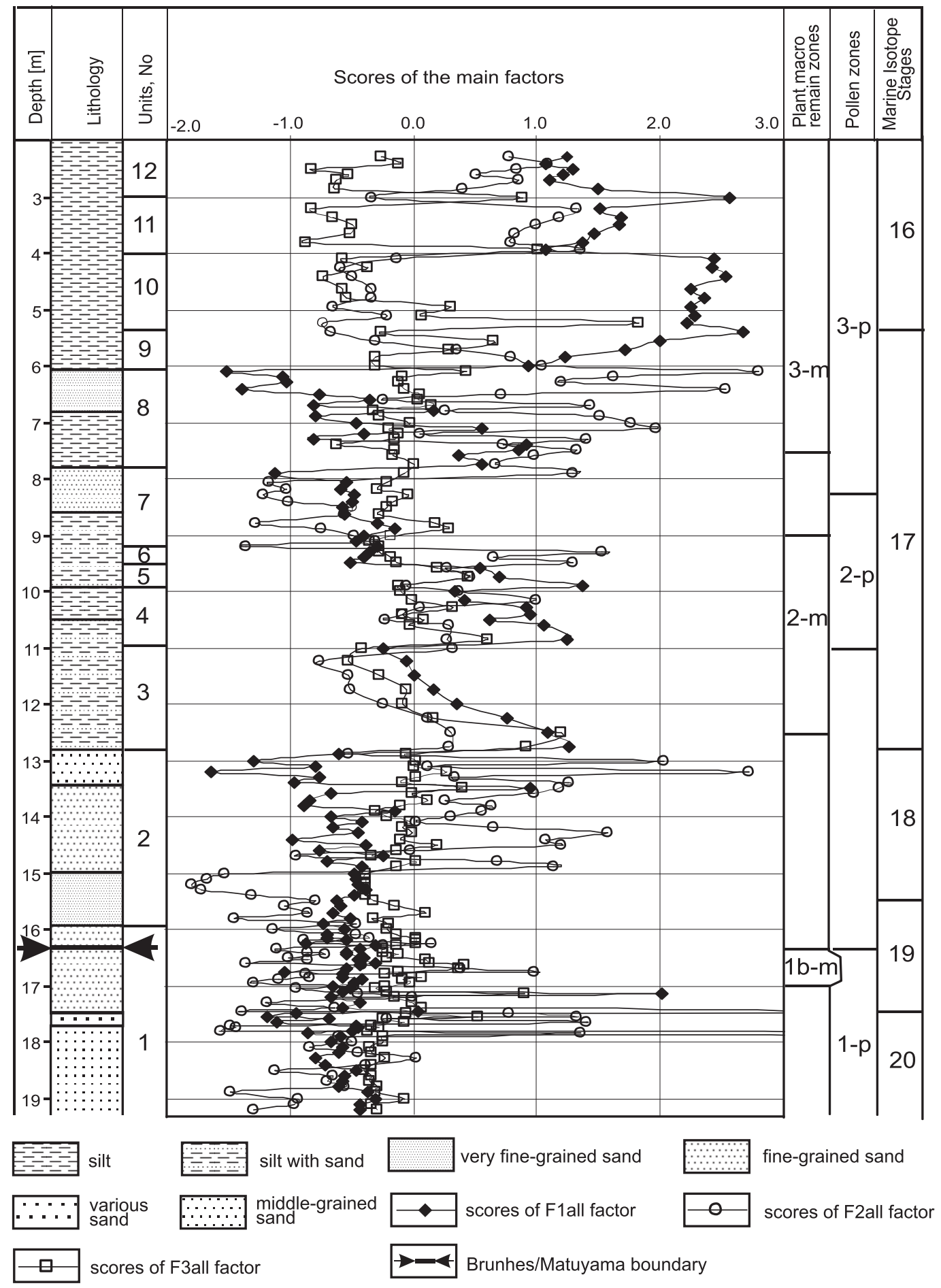

Fig. 8. Summary chart of palaeoenvironmental changes, based on all data obtained from the Daumantai-1 section

content, especially in unit $\mathrm{V}$, is explained by the high quartz content because the underlying Devonian and Neogene deposits in the study area are represented by sand with a high quartz content. According to the distribution pattern of the minerals in the $0.1-0.2 \mathrm{~mm}$ fraction of the Daumantai- 1 section described by Šinkūnas et al. (2001), the quartz content exceeds $78 \%$. The upwards decrease of Si from unit $\mathrm{V}$ to unit III and the increase of most other chemical elements is the result of a decrease in the quartz content and an increase in the admixture of the other minerals, which is also the result of a decrease in average grain size in the units. This interpretation is in accord with the lithology of the section and with the results of Šinkūnas et al. (2001).

The high percentage of samples with contents of $\mathrm{Ca}, \mathrm{Mg}, \mathrm{S}$ and $\mathrm{Na}$ less than the detection limit in the two lower units indicates their significant weathering. 
A
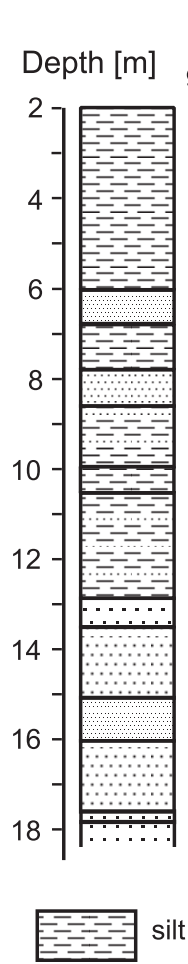

silt with sand

very fine-grained sand
B

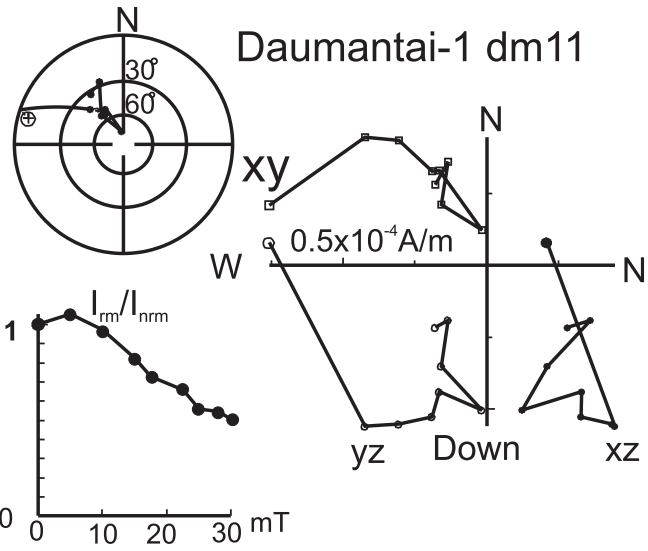

C

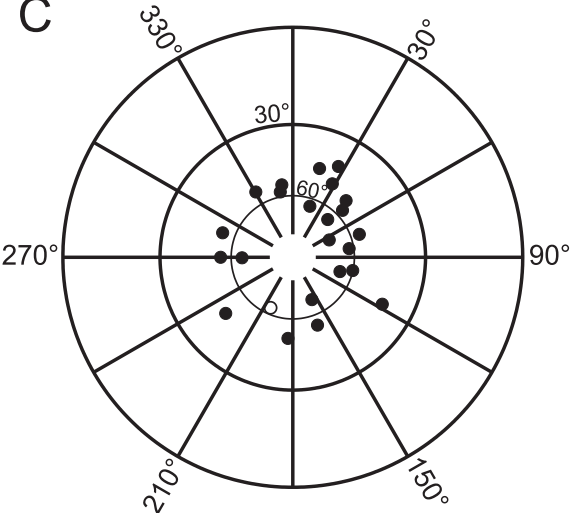

$\because \because \cdots$ middle-grained sand

$\therefore \because$ various sand

Fig. 9. Magnetic polarity scale from the Daumantai-1 section including inclination and declination data, white - reversed polarity, black - normal-polarity (A), representative demagnetization data (demagnetization track stereographic projections, intensity decay curves, orthogonal demagnetograms) of sample dm11; in stereoplots, open (closed) symbols denote upwards (downwards) pointing inclination; $I_{r m} / I_{n r m}-$ normalised intensity of remanent magnetization (B) and stereographic plots with palaeomagnetic line-fit directions at specimen levels (C)

The upwards increase in TOC and TIC and in the content of all chemical elements (except $\mathrm{Si}$ ) possibly results from the input of new material from a less-weathered source and more favourable conditions for the settling of organic matter and carbonates in calmer conditions. Thus, two factors influencing the distribution pattern in the section can be established: 1) the ratio of the local strongly weathered and the distant less-weathered materials and 2) current speed.

According to the average values of the geochemical data, the two lower units (IV and V) are similar, and the upper unit (III) differs greatly from them.

The highest variation coefficient values in unit $V$ can be explained by silt interlayers with elevated contents of clay, organic matter, sulphides, and, to an extent, carbonates.

\section{VARIATION IN MAGNETIC SUSCEPTIBILITY (MS)}

The magnetic susceptibility of rocks may be controlled by paramagnetic minerals, often by ferromagnetic minerals and much less frequently by diamagnetic minerals (Hrouda et al., 2009).

An increase in MS from unit $\mathrm{V}$ to unit III in the Daumantai-1 section can be related to a decrease in quartz, which has relatively little MS; these opposite tendencies also explains the negative correlation of $\mathrm{MS}$ with $\mathrm{Si}$. The higher correlation coefficient of $\mathrm{MS}$ with $\mathrm{Al}, \mathrm{Mg}, \mathrm{K}$, Th, $\mathrm{Rb}, \mathrm{Pb}, \mathrm{Ga}$ and $\mathrm{Ba}$ compared with that with $\mathrm{Fe}$ indicates that the increase in MS occurs not only in layers with an elevated content of ferromagnetic magnetite but also in layers with an increased content of mafic silicates and clay minerals.

The peaks in MS values in the silt layers of unit $\mathrm{V}$ may be caused by magnetite, ilmenite or Fe sulphides. The mineralogical investigations of Šinkūnas et al. (2001) show a significant content of ilmenite and magnetite in units $\mathrm{V}$ and IV. According to the correlation of MS with chemical composition, magnetite is assumed to be the main reason for the MS peaks in the lower unit. The coinciding peaks of $\mathrm{Fe}$ and $\mathrm{Ti}$ at depths of 13.5 and $12.75 \mathrm{~m}$ in unit IV suggest that ilmenite possibly caused the MS increase (Fig. 5). However, as there is only an Fe peak but not a Ti peak at a depth of $14.5 \mathrm{~m}$, magnetite should be the main cause of this increase. 


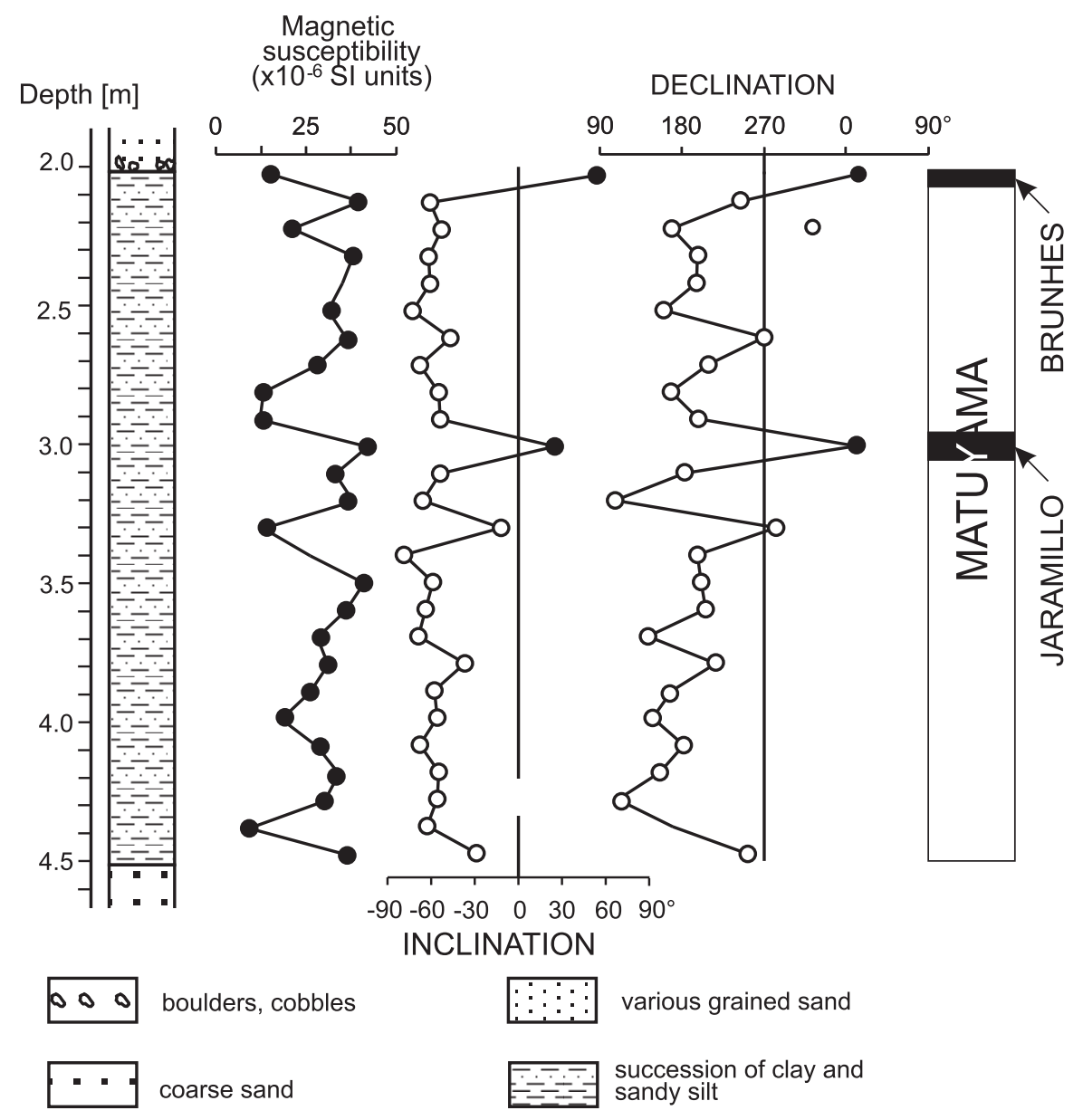

Fig. 10. Magnetic polarity scale from the Daumantai-3 section including inclination and declination data

White - reversed polarity, black - normal-polarity

According to the mineralogical investigations of Šinkūnas et al. (2001), the content of the ilmenite and magnetite in unit III decreases from 30 to $5 \%$. By contrast, the content of the non-magnetic or weakly magnetic leucoxene in units $\mathrm{V}$ and IV is $30-40 \%$ but increases from $40 \%$ to $60 \%$ in unit III. The mafic silicates are most likely the main reason for the elevated MS in the upper part of unit III.

\section{FACTORS AND ELEMENT RATIOS}

Advancing glaciers enable local material to be mixed with more distant material. To ascertain the primary source material (local or distant), the ratio of $\mathrm{Al} / \mathrm{Si}$ might be useful in the terrigenous sequences because $\mathrm{Si}$ represents quartz and $\mathrm{Al}$ represents clay or other silicates. The analogous ratio of $\mathrm{SiO}_{2} / \mathrm{Al}_{2} \mathrm{O}_{3}$ reflects grain size, among other things (Bhuiyan et al., 2011).

As the local underlying rocks are significantly weathered, the degree of weathering of the overlying part of a section is one of the most important indices indicating the state of the deposited material and enabling more reliable recognition of its main source. The ratios of the mobile-to-immobile chemical elements characterize the degree of weathering (Muhs et al.,
2008). The $\mathrm{Ca} / \mathrm{Zr}$ index is one of the indices indicating the degree of chemical weathering (Rech et al., 2001).

The ratios of two immobile chemical elements (e.g., the Ti/Zr ratio) help to distinguish different provenance rock types (e.g., granites have larger $\mathrm{Zr} / \mathrm{Ti}$ values compared with basic igneous rocks; Scheffler et al., 2006). This ratio also characterizes changes in the source of the detrital heavy mineral content (Muhs et al., 2008). Dellwig et al. (2000) found that $Z r$ is a more sensitive indicator of heavy minerals than is $\mathrm{Ti}$, because $\mathrm{Ti}$ is to a larger extent bound to clay minerals in addition to the heavy mineral fraction. Thus, an increase in the $\mathrm{Zr} / \mathrm{Ti}$ ratio should indicate a greater influence of the heavy minerals compared with clay.

Factor F1all helps to distinguish the Si related to quartz from the chemical elements related to other silicates (especially clay minerals), partly to the TOC and TIC. The similarity of the distribution of $\mathrm{F} 1 \mathrm{all}, \mathrm{Al} / \mathrm{Si}$ and $\mathrm{Ca} / \mathrm{Zr}$ can be explained by the fact that the local material is both rich in quartz and strongly weathered. To conclude, the necessary information on both ratios is generalised in F1all. The major variability of quartz and Si (Fig. 4) in unit III is reflected by the distribution pattern of F1all.

Factor F2all, with the main loadings of $\mathrm{Zr}$ and $\mathrm{Hf}$, is probably related to heavy minerals, primarily zircon. F2all might be a factor of the hydrodynamic conditions because the main loadings are formed by elements that are often related to heavy miner- 


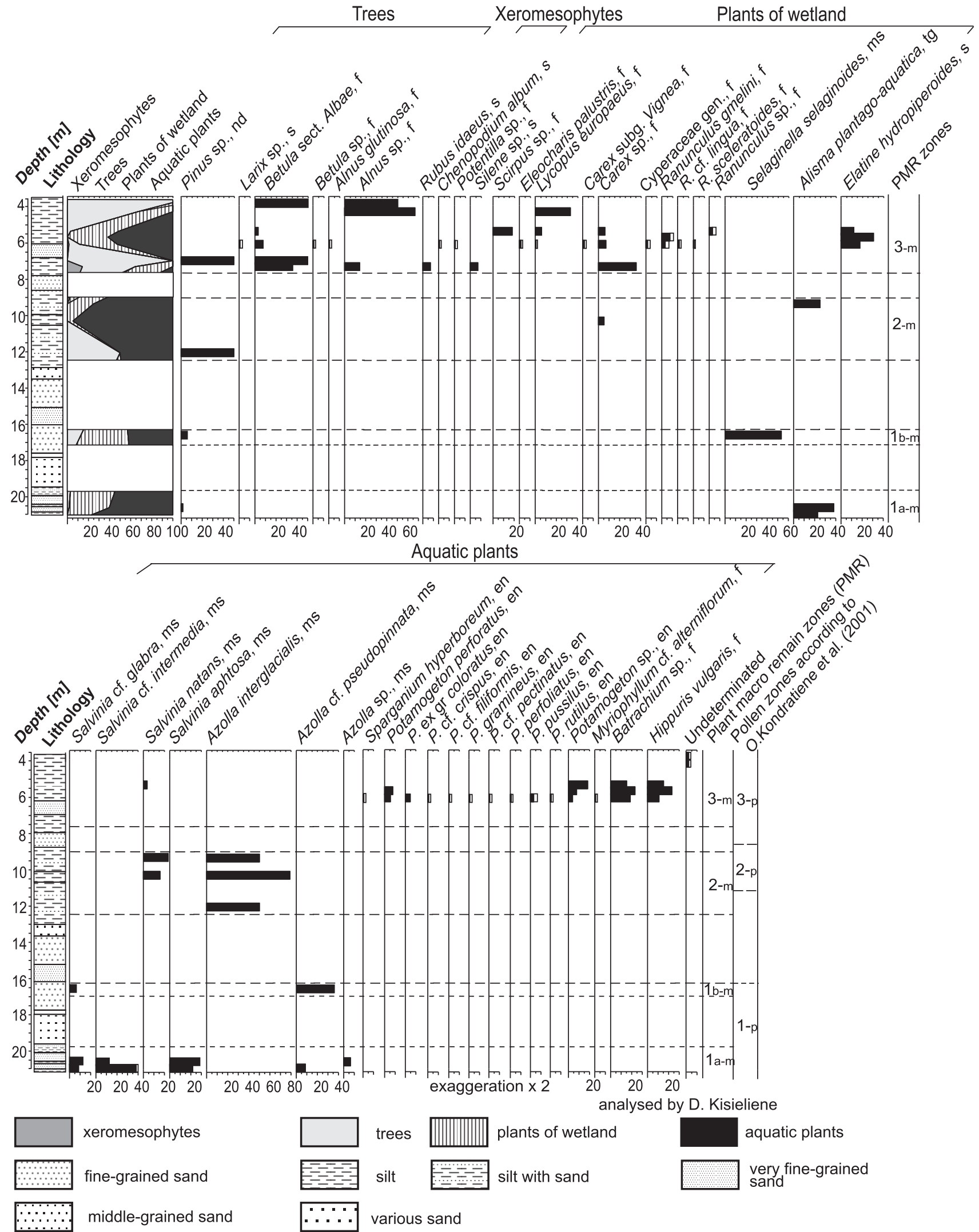

Fig. 11. Plant macrofossil diagram from the Daumantai-1 section

en - endocarp, $\mathrm{f}$ - fruit, $\mathrm{ms}$ - megaspore, $\mathrm{nd}$ - needle, $\mathrm{s}$ - seed, $\mathrm{tg}$ - tegmen 
als. The significant variabilities of $\mathrm{Zr}, \mathrm{Hf}, \mathrm{P}, \mathrm{Mn}, \mathrm{Y}, \mathrm{Na}$ and $\mathrm{Sr}$ in unit IV (Fig. 4) are reflected in the distribution of scores of this factor because these elements have significant loadings of this factor. The joint distribution of scores of two factors (F1all and F2all) might provide information regarding the relative influence of the heavy minerals in comparison to the light minerals. When only the major elements the TOC and TIC are analysed, the influence of the local strongly weathered and the distant less-weathered material is difficult to distinguish from the influence of the hydrodynamic conditions. Achieving this aim is possible when the trace elements are added and, as a result, the additional factor F2all is distinguished. There is difference between the distributions of $\mathrm{Zr} / \mathrm{Ti}$ and F2all (Figs. 7 and 8), which are related to heavy minerals. Because the specific gravities of ilmenite (4.7) and of zircon (4.6-4.7), which were found during the mineralogical investigations of Šinkūnas et al. (2001), are similar, the $\mathrm{Zr} / \mathrm{Ti}$ ratio weakly reflects the intensity of river flow. Presumably, this ratio reflects the proportion of the heavy minerals in the total amount of heavy or light minerals, except for quartz. This presumption is based on the fact that Ti has significant loadings on both F1all and F2all and Zr only on F2all; this finding is similar to that of Dellwig et al. (2000).

Factor F3all (S, As, TOC have the greatest loadings) is probably related to organic matter and sulphides. These three elements have the greatest loadings of the factor F3all, so the distribution pattern of F3all helps to identify the silt interlayers enriched in organic matter and sulphides.

\section{SEDIMENTARY ENVIRONMENT}

The changes in the relative input of the local material compared with the distant material (L/D) are the opposite of the changes of F1all and Al/Si (Figs. 7 and 8). The changes of L/D are of course related to changes in grain size. This relation is clear because the finer the grain-size, the less quartz content and the more content of other minerals. However, the sudden decrease of $L / D$ at the bottom of a unit does not always coincides with changes in the grain size (e.g., at the U3/U4, U4/U5 boundaries). Sometimes, despite the same grain size, a sudden increase of L/D is observed (e.g., at the U5/U6 boundary). The following regularity was found in units U3, U4, U5 and U8: the sudden decrease of $L / D$ is followed by its gradual increase. This regularity means that often there was a cycle with a sudden increase in the influence of distant material followed by the gradual return to a more pronounced influence of local material. The situation was different in unit U9 when a sudden decrease in L/D was followed by its gradual decrease, which indicates longer influence of the distant transported material.

The changes in weathering degree (WD) are very similar to the changes in L/D. The sudden decrease in L/D at the bottom of certain units in most cases corresponds to the sudden, though sometimes gradual, increase in MS. The contents of organic matter or sulphides usually also increase, as in part do carbonates.

The 2 lowermost units (U1 and U2) are characterized by a dominant influence of local material (L/D variable) and the large fluctuations in the content of heavy minerals (F2all), indicating that the hydrodynamic conditions were unstable. This instability might be the result of short-term climate changes.

By contrast, the uppermost four units (U9, U10, U11 and $\mathrm{U12}$ ) are characterized by a lack of influence of local material
(L/D) and small fluctuations in heavy minerals, (F2all) indicating that the hydrodynamic conditions were stable.

The distribution pattern of the $\mathrm{Zr} / \mathrm{Ti}$ variable in the uppermost four units of silt (U9-U12) demonstrates that the proportion of heavy minerals in the total amount of heavy and light minerals was small and almost constant. On the other hand, the fluctuations of $L / D$ are highly variable in the uppermost four units; the variability in light minerals from distant sources is significant. The boundaries between the 4 uppermost units are determined by the high peaks of organic matter (TOC) or sulphides (F3all).

The lower transitional units U3, U4, U5, U6 are characterized by small fluctuations of hydrodynamic conditions (F2all) and small fluctuations in the input of heavy minerals $(\mathrm{Zr} / \mathrm{Ti})$ but also by more distinct trends, especially for $\mathrm{Zr} / \mathrm{Ti}$, which increases upwards, although it commonly decreases at the bottom of these units.

The upper transitional units $\mathrm{U} 7$ and $\mathrm{U} 8$ are characterized by the change from small fluctuations to large fluctuations in $\mathrm{Zr} / \mathrm{Ti}$ and F2all. Both in U7 and in U8, the $\mathrm{Zr} / \mathrm{Ti}$ increases and indicates the short-term variability of stream flow and its increasing trend. The boundary between U7 and U8 is characterized by a decrease in $\mathrm{Zr} / \mathrm{Ti}$.

\section{CONCLUSIONS}

1. Analysis of the Daumantai sections has elucidated changes in the sedimentary environment during the Early-Middle Pleistocene transition and has constrained the local level of the Early/Middle Pleistocene boundary.

2. Using information contained in the distribution pattern of the F1all scores, 11 boundaries and 12 units were distinguished according to this variable, which has a distribution similar to the $\mathrm{Al} / \mathrm{Si}$ and $\mathrm{Ca} / \mathrm{Zr}$ ratio and indicates significant palaeoenvironmental changes (fluctuations in temperature and hydrodynamical conditions, distal/local source changes, weathering degree).

3. The two lowermost units $U 1$ and $U 2$ are characterized by a strong influence of local material and high fluctuations in the content of heavy minerals, indicating that the hydrodynamic conditions were unstable. The transitional units U3, U4, U5 and U6 are characterized by small fluctuations of hydrodynamic conditions and in the input of heavy minerals.

4. The upper transitional units (U7 and U8) are characterized by change from small fluctuations to large fluctuations of the input of heavy minerals and of hydrodynamic conditions.

The uppermost 4 units (U9, U10, U11, and U12) are characterized by a small influence of local material and small fluctuations in heavy minerals, indicating that the hydrodynamic conditions were stable.

5. The results of the palaeomagnetic investigations and the detection of the boundary of the Bruhnes/Matuyama reversal (at the depth of $16.50 \mathrm{~m}$ ) enable the recognition of intervals referable to the Early, Middle and Late Pleistocene.

6 . In the Daumantai-1 section the clearly expressed lithological and textural boundary at a depth of $19.15 \mathrm{~m}$ fixes the Neogene (Pliocene)/Quaternary (Pleistocene) boundary, which is consistent with palaeobotanical data.

7. The determination of those two boundaries enables the correlation of the interval of 15.5-17.45 m with MIS 19 (760-787 ka; Bruhnes/Matuyama boundary is $780 \mathrm{ka}$ ). In the rest of the section, the interval $2.8-15.5 \mathrm{~m}$ possibly correlates 
with MIS 18, the interval 5.3-12.8 $\mathrm{m}$ with MIS 17, and the interval 2.2-5.3 $\mathrm{m}$ with MIS 16 .

8. Below the Bruhnes/Matuyama boundary in the Daumantai-1 section and above the Jaramillo subchron (0.99-1.07 ka) in the Daumantai-3 section, MIS 20-31 deposits may be expected, but the process of identifying these is incomplete.
Acknowledgements. The authors are grateful to the Research Council of Lithuania for their support of the project "Ciklas" (reg. No LEK-10008, agreement No LEK-01/2010) and to a large working team for their assistance in the implementation of the project. A. Raukas, A. Ber and an anonymous reviewer are thanked for their valuable comments and suggestions which helped to improve the paper.

\section{REFERENCES}

Baltakytè-Vienožinskienè A. (1956) Kai kurie Lietuvos TSR vadinamuju preglacialiniu dariniu palinologiniu tyrimu duomenys. Lietuvos TSR MA Darbai, serija B, 4 (7): 69-77.

Baltrūnas V. (2002) Stratigraphical subdivision and correlation of Pleistocene deposits in Lithuania (methodical problems). Institute of Geology, Vilnius.

Battarbee R.W. (1986) Diatom analysis. In: Handbook of Holocene Palaeocology and Palaeohydrology (ed. B.E. Berglund): 527-570. John Wiley and Sons, Chichester.

Ber A. (2000) Pleistocene of north-eastern Poland and neighbouring areas against crystalline and sedimentary basement (in Polish with English summary). Prace Państwowego Instytutu Geologicznego, 170.

Ber A. (2006) Pleistocene interglacials and glaciations of northeastern Poland compared to neighbouring areas. Quaternary International, 149 (1): 12-23.

Ber A., Lindner L., Marks L. (2007) Proposal of a stratigraphic subdivision of the Quaternary of Poland (in Polish with English summary). Przeglad Geologiczny, 55 (2): 115-118.

Berggren G. (1969) Atlas of seeds and small fruits of Northwest-European plant species with morphological descriptions. Part 2, Cyperaceae. Berlingska Boktryckeriet, Lund.

Berggren G. (1981) Atlas of seeds and small fruits of Northwest-European plant species with morphological descriptions. Part 3, Salicaceae-Cruciferae. Berlings, Arlöv.

Bhuiyan M.A.H., Rahman M.J.J., Dampare S.B., Suzuki S. (2011) Provenance, tectonics and source weathering of modern fluvial sediments of the Brahmaputra-Jamuna River, Bangladesh: inference from geochemistry. Journal of Geochemical Exploration, 111: 113-137.

Cappers R.T.J., Bekker R.M., Jans J.E.A. (2006) Digital seed atlas of the Netherlands. Barkhius publishing and Groningen university library, Groningen.

Cohen K.M., Gibbard P.L. (2011) Global chronostratigraphical correlation table for the last 2.7 million years. University of Cambridge, Utrecht University, INQUA.

Dalinkevičius J. (1928) Nauji bruožai apie Šiaures Lietuvą ir Kuršo geologiją ir ju ryšiai su Vidurine Lietuva. Kosmos, 9 (7-8): 339-366.

Dalinkevičius J. (1944) Lietuvos pleistoceno stratigrafiniai bruožai. Technika, 4: 10-14.

Dellwig O., Hinrichs J., Hild A., Brumsack H.-J. (2000) Changing sedimentation in tidal flat sediments of the southern North Sea from the Holocene to the present: a geochemical approach. Journal of Sea Research, 44: 195-208.

Gaigalas A.I. (1987) Neogene-Quaternary boundary in Baltic region (in Russian with English summary). In: The Boundary Between the Neogene and Quaternary Systems on the USSR (eds. M.N. Alekseev and K.V. Nikiforova): 13-26. Nauka, Moscow.

Gaigalas A. (1995) Glacial history of Lithuania. In: Glacial Deposits in North-East Europe (eds. J. Ehlers, S. Kozarski and Ph. Gibbard): 127-135. A.A. Balkema, Rotterdam.
Gibbard P.L., Cohen K.M. (2008) Global chronostratigraphical correlation table for the last 2.7 million years. Episodes, 31 (2): 243-247.

Grigas A. (1986) Lietuvos augalu vaisiai ir seklos. Mokslas, Vilnius.

Gudžinskas Z. (1999) Lietuvos induočiai augalai. Institute of Botany, Vilnius.

Guobytè R., Satkūnas J. (2011) Pleistocene Glaciations in Lithuania. In: Developments in Quaternary Science (eds. J. Ehlers, P.L. Gibbard and P.D. Hughes): 231-246. Amsterdam, The Netherlands.

Halicki B. (1938) Materialy do znajomości budowy podłoża Polski północno-wschodniej. Prace Towarzystwa Przyjaciół Nauk w Wilnie, 12: 174-211.

Hrouda F., Chlupáčová M., Chadima M. (2009) The use of magnetic susceptibility of rocks in geological exploration (case histories study). Terraplus, Geophysical equipment supplier, Brno.

Kaveckis M. (1928) Lietuvos geologines ekspedicijos darbu apyskaitos. Spindulys, Kaunas.

Kisieliené D. (2002) Palaeocarpological complexes of Lithuania Quaternary and their stratigraphical significance. Ph.D. thesis, Institute of Geology and Geography, Vilnius.

Klimašauskas A., Prakapaitè G. (1971) Lithologische Zusammensetzung der Ablagerungen des Unterpleistozäns Litauens (in Russian with German summary). In: Aufbau, lithologie und stratigraphie der Ablagerungen des Unterpleistozäns in Litauen (eds. P. Vaitiekănas and O. Kondratienè): 35-56. Mintis, Vilnius.

Kondratiene O. (1996) The Quaternary stratigraphy and paleogeography of Lithuania based on paleobotanic studies (in Russian with English summary). Academia, Vilnius.

Kondratienè O., Riškienè M. (1971) Palaobotanisch wurden die Ablagerungen des Unterpleistozans untersucht (in Russian with German summary). In: Aufbau, lithologie und stratigraphie der Ablagerungen des Unterpleistozäns in Litauen (eds. P. Vaitiekănas and O. Kondratiene): 57-115. Mintis, Vilnius.

Kondratienè O., Šinkūnas P., Barzdžiuvienè V. (2001) Daumantai-1 outcrop - the stratotype of Neogene/Quaternary boundary. In: Field Symposium on Quaternary Geology in Lithuania. Excursion guide, 19-25 May, Geological Survey of Lithuania, Institute of Geology, Vilnius: 20-26.

Lindner L., Marks L. (2008) Pleistocene stratigraphy of Poland and its correlation with stratotype sections in Volhynian Upland (Ukraine). Geochronometria, 31: 31-37.

Lindner L., Gozhik P., Marciniak B., Marks L., Yelovicheva Y. (2004) Main climatic changes in the Quaternary of Poland, Belarus and Ukraine. Geological Quarterly, 48 (2): 97-114.

Lindner L., Bogutsky A., Gozhik P., Marks L., Łanczont M., Wojtanowicz J. (2006) Correlation of Pleistocene deposits in the area between the Baltic and Black Sea, Central Europe. Geological Quarterly, 50 (1): 195-210.

Makhnach A.V., Garetskii R.G., Matveev A.V., eds. (2001) Geologia Belorussii. Institut geologicheskikh nauk, Minsk.

Malinauskas Z.A. (1985) Granitsa neogena-pleistotsena po litologicheskim dannim Litovskoi SSR. Geologicheskie issledovania i 
izuchenie mineralno-sirevoi bazy Litovskoi SSR. Vilnius, LitNIGRI: 53-54.

Miller U., Florin M.-B. (1989) Diatom analysis. Introduction to methods and applications. PACT, 24: 133-157.

Molodkov A.N., Bolikhovskaya N.S. (2002) Eustatic sea-level and climate changes over the last $600 \mathrm{ka}$ as derived from mollusc-based ESR-chronostratigraphy and pollen evidence in Northern Eurasia. Sedimentary Geology, 150 (1-2): 185-201.

Muhs D.R., Ager T.A., Skipp G., Beann J., Budahn J., McGeehin J.P. (2008) Paleoclimatic significance of chemical weathering in loess-derived paleosols of Subarctic Central Alaska. Arctic, Antarctic, Alpine Research, 40 (2): 396-411.

Narbutas V., Uginčius A. (2001) Lietuvos vidurinio devono terigeniniai kompleksai. Akstis, Vilnius.

Pevzner M.A., Gaigalas A. (1976) Ostatochnaia namagnichenost'. In: Pogrebionnye paleovrezy poverkhnosti dochetvertichnykh porod iuzhnoi pribaltiki (ed. A. Gaigalas): 65-75. Mokslas, Vilnius.

Rech J.A., Reeves R.W., Hendricks D.M. (2001) The influence of slope aspect on soil weathering processes in the Springerville volcanic field, Arizona. Catena, 43 (1): 49-62.

Richmond G.M. (1996) The INQUA-approved provisional Lower/Middle Pleistocene boundary. In: The Early Middle Pleistocene in Europe (ed. T. Turner): 319-327. Balkema, Rotterdam.

Satkūnas J., Grigienè A., Bitinas A. (2007) Stratigraphic division of the Lithuanian Quaternary: the present state (in Lithuanian with English summary). Geologijos akiračiai, 1: 38-46.
Scheffler K., Buehmann D., Schwark L. (2006) Analysis of late Palaeozoic glacial to postglacial sedimentary successions in South Africa by geochemical proxies - response to climate evolution and sedimentary environment. Palaeogeography, Palaeoclimatology, Palaeoecology, 240: 184-203.

Šinkūnas P., Barzdžiuvienè V., Jurgaitis A. (2001) Sedimentological aspects of deposits in Daumantai and Vetygala outcrops (in Lituanian with English summary). Litosfera, 5: 67-79.

Šliaupa A. (2004) Prekvartero uolienu paviršius. In: Lietuvos Žemes gelmiu raida ir ištekliai (ed. V. Baltrūnas): 254-258. Petro ofsetas, Vilnius.

Tiessen H., Moir J.O. (1993) Total and organic carbon. In: Soil Sampling and Methods of Analysis (ed. M.E. Carter): 187-211. Lewis Publishers, Ann Arbor, MI.

Vaitiekūnas P.P. (1977) Die Präpleistozänen Ablagerungen im Bereich des Šventoji-Flusses (in Russian with German summary). Geografija ir geologija, 13: 73-90.

Velichkievich F.Yu. (1982) Pleistotsenovye flori lednikovikh oblastey Vostochno-Evropeiskoy ravniny. Nauka i tekhnika. Minsk.

Winter H., Khursevich G., Fedenya S. (2008) Pollen and diatom stratigraphy of the lacustrine-fluvial-swamp deposits from the profile at Domuraty, NE Poland. Geological Quarterly, 52 (3): 269-280.

Yakubovskaya T.V. (1998) Revision of the stratigraphy of the Eopleistocene (Lower Pleistocene) of Belarus (in Russian with English summary). Lithosphere, 9: 25-28. 